\title{
Evaluation of Health-Related Quality of Life among Children Attending Asthma Clinic in Alexandria University Children's Hospital
}

Authors

Maged Mohamed Eissa ${ }^{1}$, Ghada Farouk Elderiny ${ }^{2}$, Amr Gamal Elbanna ${ }^{3}$

${ }^{1}$ Professor of Pediatrics, Faculty of Medicine, Alexandria University

${ }^{2}$ Lecturer of Pediatrics, Faculty of Medicine, Alexandria University

${ }^{3}$ Demonstrator of Pediatrics, Faculty of Medicine, Alexandria University

\section{ABSTRACT}

Objectives: To evaluate health-related quality of life (HRQL) among children attending asthma clinic in Alexandria university children's hospital.

Methods: 120 asthmatic children attending at Alexandria university children's hospital will undergo clinical examination and spirometric evaluation to determine their level of asthma control. The studied asthmatic children will be asked to answer the pediatric asthma quality of life questionnaire (PAQLQ) to evaluate their quality of life (QoL).

Results: The age of the studied children ranged from 7-14 years with a mean of $10.35 \pm 2.23$ years. They were $50.8 \%$ males and $49.2 \%$ females. The majority (40\%) were of low socioeconomic status. Normal weight children were the majority representing $48.2 \%$, while the obese ones were $25 \%$. Well controlled patients were $60.0 \%$, the partially controlled patients were $24.2 \%$ and the uncontrolled patients were $15.8 \%$. The overall QoL score correlated well to the degree of asthma control. There was a significant positive correlation between FEVI and overall PAQLQ score. Score of symptoms was the most affected score among children with different levels of asthma control. Level of asthma control, body mass index (BMI), socioeconomic level and residence affected QoL significantly and considered as the main determinants to QoL in the studied children.

Conclusion: Asthma greatly affected the QoL of asthmatic children. Knowing the main determinants of the QoL in affected children helps to improve their QoL.

Degree of asthma control, socioeconomic status, residence and BMI are the main determinants of overall QoL score among the studied children. Improving these QoL determinants might help to improve QoL of these children.

Keywords: Asthma, Quality of life, Asthma control, Spirometry.

\section{INTRODUCTION}

Asthma is a chronic inflammatory disorder of the airways in which many cells and cellular elements play a role. The chronic inflammation is associated with airway hyperresponsiveness that leads to recurrent episodes of wheezing, breathlessness, chest tightness, and coughing particularly at night or in the early morning. These episodes are usually associated with a widespread, but variable, airflow obstruction within the lung that is often reversible either spontaneously or with treatment. ${ }^{(1)}$

Asthma is the most frequent chronic disorder in childhood. Asthma puts a serious burden on children's HRQL, despite the availability of effective and safe treatment. ${ }^{(2,3)}$ 
In Egypt, the prevalence of asthma among school children in the Nile Delta region is about $7.7 \% .^{(4)}$ Asthma is relatively common in Egypt, and probably under diagnosed and under treated, particularly among children from less wealthy families. ${ }^{(5)}$ It is a public health problem not just for high-income countries; it occurs in all countries regardless of the level of development. ${ }^{(6)}$

Pediatric asthma accounts for a large proportion of childhood hospitalizations, healthcare visits, absenteeism from day care/school and missed work days by parents. For example, in Egypt up to one in four children with asthma is unable to attend school regularly because of poor asthma control. ${ }^{(7)}$

The overall goal of asthma management is to achieve optimal disease control and HRQL improvements. ${ }^{(8)}$ Conventional clinical measures of asthma control such as symptoms, medication requirements and spirometry usually provide valuable information about the status of the affected organ system but they rarely capture the functional impairments (physical, emotional and social) that are important to the patients in their everyday lives. ${ }^{(9,10)}$

HRQL is "a range of capabilities, limitations, symptoms and psychosocial characteristics that describe an individual's ability to function and derive satisfaction from a variety of roles. ${ }^{(1)}$

The progressive use of HRQL measures have shown great potential for improving the health care of patients, particularly those with chronic conditions. ${ }^{(2,13)}$ When such measures have been developed in a country other than that in which they will be applied, the appropriateness of the validation process (translation into the local language and adaptation for use in the target cultural context) is as important as is the selection of the instrument itself. ${ }^{(14)}$

Asthma-specific QoL questionnaires have been developed to quantify, in a formal and standardized way, the effects of asthma on the patient's daily life and well-being, and the extent to which a given treatment reduces these effects. Probably the greatest challenge in measuring child and adolescent HRQL is not only to capture the individual perspective, but also to accommodate the physical, emotional and social changes that occur as the child develops and understands the concepts that are being addressed. ${ }^{(15)}$

Pediatric asthma quality of life questionnaire (PAQLQ) measures the functional (physical, emotional, occupational and social) problems that are most troublesome to children (7-17 years) with asthma. ${ }^{(9,16)}$ It has 23 questions in three domains (symptoms, activity limitation and emotional function). The PAQLQ has a time specification of one week so children were asked to recall their experiences during the previous week; there is evidence that this is the maximum length of time over which younger children can recall their experiences with any degree of accuracy. ${ }^{(17,18)}$

\section{AIM OF THE STUDY}

To evaluate HRQL among children attending asthma clinic in Alexandria university children's hospital and identify its main determinants.

\section{SUBJECTS AND METHODS}

This study was carried out on 120 asthmatic children aged 7 to 15 years attending asthma and allergy clinic of Alexandria University Children's hospital. They were $61(50.8 \%)$ males and 59 (49.2\%) females. Families of these children were from both urban and rural communities and of varied socioeconomic backgrounds. It was conducted during the period starting from April 2016 to March 2017. The study protocol was approved by the Local Ethics Committee of Scientific Research, Faculty of Medicine, Alexandria University. Verbal consent was taken from the caregivers of the participants and verbal assent was taken from the children older than 7 years. PAQLQ used in the study was obtained from the QOL TECHNOLOGIES Ltd after approval from Jilly Styles (Personal Assistant to Professor Elizabeth Juniper, McMaster University Canada). The approval was sent through email. 


\section{Research strategy}

\section{Inclusion criteria}

Any asthmatic child aged 7-15 years attending at asthma and allergy clinic of Alexandria University Children's hospital.

\section{Exclusion criteria}

Any asthmatic child who has associated chronic illness, or who cannot understand the PAQLQ or cannot perform spirometry was excluded from the study

\section{Study measurements and tools}

I. Clinical evaluation

Detailed history was taken with special emphasis on treatment given. Patients were classified according to treatment given into those who are using leukotriene receptor antagonist (LTRA), those using inhaled corticosteroids (ICS) with any dose either alone or combined with LTRA or long acting $\beta$ agonist (LABA) and those who are using systemic steroids. Each patient was subjected to general examination as well as chest examination. Level of asthma control was determined.

\section{Pediatric asthma quality of life questionnaire (PAQLQ) ${ }^{(10)}$}

It measures the functional (physical, emotional, occupational and social) problems that are most troublesome to children with asthma. It has a 23 questions in three domains (symptoms, activity limitation and emotional functions) with a time specification of one week so children were asked to recall their experiences during the previous week and to respond to each question on a 7-point scale ( $7=$ no impairment, $1=$ severe impairment). Three of the activity questions were "patientspecific" so each child can identify and choose the three most limited activities due to his asthma.

Number of questions in each domain is as follow:

Activity limitation: 5 (2 generic, 3 patient specific)

Symptoms: 10

Emotional function: 8

The 23 questions in the PAQLQ are divided into 3 domains as follow:
Domain

Activity limitation

Symptoms

Emotional functions questions

$1,2,3,19,22$

$4,6,8,10,12,14,16,18,20,23$

$5,7,9,11,13,15,17,21$

The overall PAQLQ score was the mean of the responses to each of the 23 questions. The resultant overall score would be between 1 and 7 . Domain scores were also the mean values for the items in each domain so that the score of each domain would be also between 1 and 7 .

The interviewer form of Arabic version of PAQLQ was used while the child was provided by a card illustrating the 7-point scale from which he or she chooses the answer that best describes his or her experiences during the previous week. The PAQLQ was administered before clinical assessment and spirometry.

\section{Sociodemographic data}

\section{A. Patient related}

- Age, sex, weight, height and body mass index.

\section{B. Family related}

- Residence: either in rural or urban areas.

- Paternal smoking

- Family social level: It was assessed using the Modified Social Score for Social Leveling depending on education and work of father and mother, family income, family size, crowding index and sanitation. A score is given for each domain. Total score is the sum of all scores of all the above mentioned domains. Families were classified to those of high social level, middle social level (high and low), and low social level according to the calculated score. $^{(19)}$

\section{Disease related factors}

Level of asthma control was determined according to global initiative of asthma (GINA) guidelines. Children were classified into controlled, partly controlled and uncontrolled.

\section{Pulmonary function tests}

Spirometry was performed in the pulmonary function laboratory adjacent to the asthma clinic. Values of forced expiratory volume in 1 second 
(FEV1) and peak expiratory flow rate (PEFR) were expressed as percentage of predicted for age, weight, height and sex.

\section{RESULTS}

The age ranged from 7-14 years with a mean of $10.35 \pm 2.23$ years. They were $50.8 \%$ males and $49.2 \%$ females. As regards socioeconomic status of the studied children, $40 \%$ were low socioeconomic level, $20 \%$ were high moderate socioeconomic status, $15 \%$ were low moderate socioeconomic status and $25 \%$ were high socioeconomic status. About $69.2 \%$ of the studied children reside in urban areas, while $30.8 \%$ in rural areas. Normal weight children were the majority representing $48.2 \%$, while the obese ones were $25 \%$. The overweight represent $12.5 \%$ and those who are underweight represent $13.3 \%$. Well controlled patients were 72 cases $(60.0 \%)$, the partially controlled patients were 29 cases (24.2\%) and the uncontrolled patients were 19 cases $(15.8 \%)$.

The majority of patients were using inhaled steroids combined with LABA (33.3\%) followed by the group using ICS combined with LTRA $(25 \%)$.

It was found that the overall PAQLQ score, score of symptoms, score of activity and score of emotional function weren't affected significantly by age as shown in Table (1).

Table (1): Effect of age on different QoL scores.

\begin{tabular}{||l|c|c|c|}
\hline | & $<10$ years & $>10$ years & $\mathrm{t}, \mathrm{p}$ \\
\hline Overall PAQLQ score & & & \\
Range & $1.90-7.00$ & $1.90-7.00$ & 0.501 \\
Mean & 5.24 & 5.43 & 0.481 \\
S.D. & 1.44 & 1.52 & \\
\hline Score of symptoms & $1.8-7$ & & \\
Range & 5.06 & $1.6-7$ & 0.946 \\
Mean & 1.51 & 5.34 & 0.333 \\
S.D. & $1.9-7.1$ & & \\
\hline Score of activity limitation & 5.29 & $2.1-7$ & 0.608 \\
Range & 1.48 & 5.5 & 0.437 \\
Mean & & & \\
S.D. & $2-7$ & $2-7$ & 0.218 \\
Score of emotional function & 5.43 & 5.55 & 0.642 \\
Range & 1.37 & 1.47 & \\
Mean & \multicolumn{3}{|l}{} \\
S.D. & $t$ test P is significant if $\leq 0.05$
\end{tabular}

Table (2) illustrates that there was a significant show significant higher values than males as effect of sex on the values of all scores. Females regard the total QoL score and sub scores.

Table (2): Effect of sex on different QoL scores.

\begin{tabular}{|l|c|c|c||}
\hline & Male & Female & $\mathrm{t}, \mathrm{p}$ \\
\hline Overall PAQLQ score & & & \\
Range & $1.9-6.8$ & $2.3-7$ & \\
Mean & 4.82 & 5.89 & 17.502 \\
S.D. & 1.54 & 1.23 & $0.0076^{*}$ \\
\hline Score of symptoms & & & \\
Range & $1.6-6.6$ & $2-7$ & \\
Mean & 4.7 & 5.76 & 15.872 \\
S.D. & 1.58 & 1.32 & $0.0041^{*}$ \\
\hline Score of activity limitation & & & \\
Range & $1.9-7$ & $2.1-7.1$ & \\
Mean & 4.85 & 5.99 & 20.086 \\
S.D. & 1.51 & 1.26 & $0.0057^{*}$ \\
\hline Score of emotional function & & & \\
Range & $2-7$ & $2.8-7$ & \\
Mean & 5.06 & 5.95 & 12.917 \\
S.D. & 1.55 & 1.12 & $0.0012^{*}$ \\
\hline
\end{tabular}

$t=t$ - test $\quad P$ is significant if $\leq 0.05$ 
Table (3) shows the effect of asthma control on QoL scores and FEV1. The difference in QoL between different levels of asthma control was significant in all scores denoting that level of asthma control has a significant effect on the QoL score. FEV1 was high in well controlled patients more than partially controlled and uncontrolled patients $(\mathrm{p}<0.01)$.

Table (3): Effect of asthma control on QoL scores and FEV1.

\begin{tabular}{|c|c|c|c|c|}
\hline & Well controlled & Partially controlled & Uncontrolled & $\mathrm{F}, \mathrm{p}$ \\
\hline $\begin{array}{l}\text { Overall PAQLQ score } \\
\text { Range } \\
\text { Mean } \\
\text { S.D. } \\
\end{array}$ & $\begin{array}{c}4.40-7.00 \\
6.32 \\
0.63 \\
\end{array}$ & $\begin{array}{c}3.00-5.60 \\
4.57 \\
0.78 \\
\end{array}$ & $\begin{array}{c}1.90-4.30 \\
2.89 \\
0.78 \\
\end{array}$ & $\begin{array}{c}18.36 \\
0.0041 *\end{array}$ \\
\hline $\begin{array}{l}\text { Score of symptoms } \\
\text { Range } \\
\text { Mean } \\
\text { S.D. } \\
\end{array}$ & $\begin{array}{c}4.30-7.00 \\
6.25 \\
0.63 \\
\end{array}$ & $\begin{array}{c}2.80-5.40 \\
4.37 \\
0.79 \\
\end{array}$ & $\begin{array}{c}1.60-4.20 \\
2.67 \\
0.81 \\
\end{array}$ & $\begin{array}{c}13.65 \\
0.0052 *\end{array}$ \\
\hline $\begin{array}{l}\text { Score of activity } \\
\text { limitation } \\
\text { Range } \\
\text { Mean } \\
\text { S.D. }\end{array}$ & $\begin{array}{c}4.20-7.10 \\
6.40 \\
0.66 \\
\end{array}$ & $\begin{array}{c}2.90-6.00 \\
4.59 \\
0.83 \\
\end{array}$ & $\begin{array}{c}1.90-4.60 \\
3.02 \\
0.77 \\
\end{array}$ & $\begin{array}{c}16.52 \\
0.0063 *\end{array}$ \\
\hline $\begin{array}{l}\text { Score of emotional } \\
\text { function } \\
\text { Range } \\
\text { Mean } \\
\text { S.D. }\end{array}$ & $\begin{array}{c}4.40-7.00 \\
6.40 \\
0.66 \\
\end{array}$ & $\begin{array}{c}3.00-5.90 \\
4.78 \\
0.75 \\
\end{array}$ & $\begin{array}{c}2.00-4.80 \\
3.19 \\
0.97 \\
\end{array}$ & $\begin{array}{c}9.25 \\
0.0085^{*}\end{array}$ \\
\hline $\begin{array}{l}\text { FEV1 } \\
\text { Range } \\
\text { Mean } \\
\text { S.D. } \\
\end{array}$ & $\begin{array}{c}80.0-98.0 \\
88.25 \\
5.35 \\
\end{array}$ & $\begin{array}{c}62.00-92.00 \\
71.41 \\
7.37 \\
\end{array}$ & $\begin{array}{c}35-57 \\
43.65 \\
7.28 \\
\end{array}$ & $\begin{array}{c}22.1 \\
0.001^{*}\end{array}$ \\
\hline
\end{tabular}

Figure (1) shows that there was a significant PAQLQ score. The higher the value of FEV1, the positive correlation between FEV1 and overall better is the QoL score.

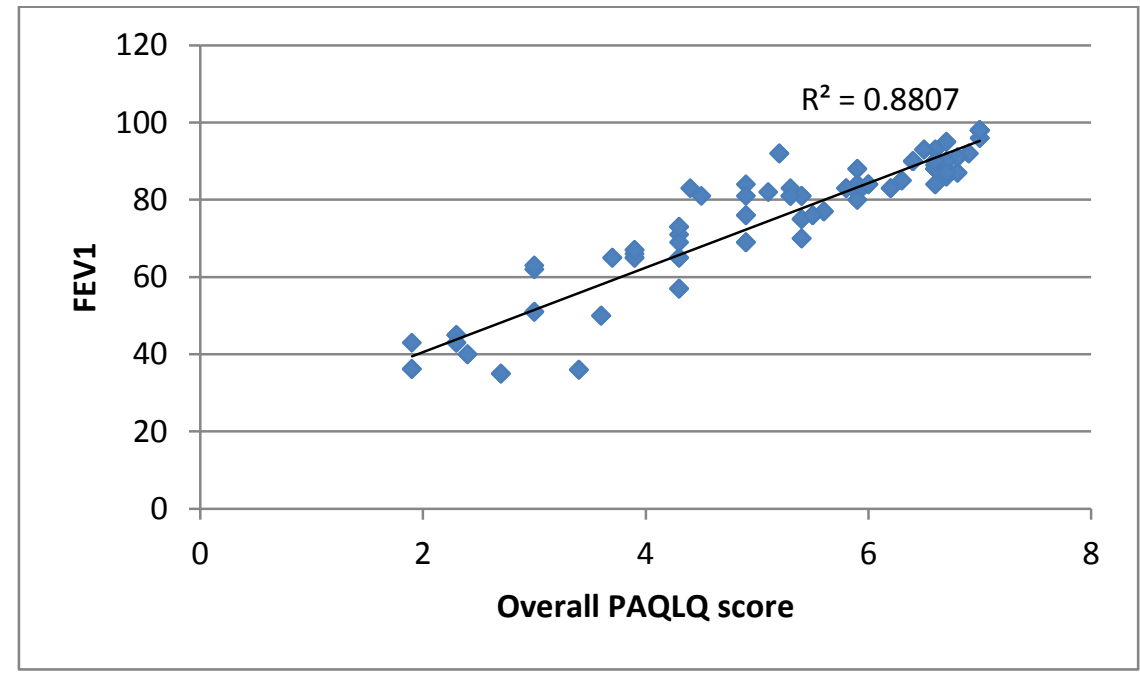

Fig. (1): Correlation between FEV1 and overall QoL score.

It was found that there was a significant effect of the socioeconomic status on the overall PAQLQ score and its subscores. Patients with high socioeconomic status had the highest overall PAQLQ score, score of symptoms, score of activity limitation and score of emotional function, while patients with low socioeconomic status had the lowest scores as shown in table (4). 
Table (4): Effect of socioeconomic status on QoL scores.

\begin{tabular}{|c|c|c|c|c|c|}
\hline & High & Moderate high & Moderate Low & Low & $\overline{F, p}$ \\
\hline $\begin{array}{l}\text { Overall PAQLQ score } \\
\text { Range } \\
\text { Mean } \\
\text { S.D. }\end{array}$ & $\begin{array}{c}3.90-7.00 \\
6.42 \\
0.97\end{array}$ & $\begin{array}{c}3.70-6.70 \\
5.99 \\
0.73\end{array}$ & $\begin{array}{c}1.90-6.70 \\
4.36 \\
1.14\end{array}$ & $\begin{array}{c}1.90-5.40 \\
3.15 \\
0.97\end{array}$ & $\begin{array}{l}64.741 \\
.0001\end{array}$ \\
\hline $\begin{array}{l}\text { Score of symptoms } \\
\text { Range } \\
\text { Mean } \\
\text { S.D. }\end{array}$ & $\begin{array}{c}3.80-7.00 \\
6.36 \\
1.00\end{array}$ & $\begin{array}{c}3.30-6.80 \\
5.86 \\
0.75\end{array}$ & $\begin{array}{c}1.80-6.70 \\
4.23 \\
1.19\end{array}$ & $\begin{array}{c}1.60-5.30 \\
2.92 \\
1.04\end{array}$ & $\begin{array}{l}64.445 \\
.0001\end{array}$ \\
\hline $\begin{array}{l}\text { Score of activity limitation } \\
\text { Range } \\
\text { Mean } \\
\text { S.D. }\end{array}$ & $\begin{array}{c}3.40-7.10 \\
6.43 \\
1.02\end{array}$ & $\begin{array}{c}3.80-7.00 \\
6.09 \\
0.79\end{array}$ & $\begin{array}{c}1.90-6.80 \\
4.46 \\
1.08\end{array}$ & $\begin{array}{c}2.10-5.40 \\
3.17 \\
1.00\end{array}$ & $\begin{array}{l}61.555 \\
.0001\end{array}$ \\
\hline $\begin{array}{l}\text { Score of emotional function } \\
\text { Range } \\
\text { Mean } \\
\text { S.D. }\end{array}$ & $\begin{array}{c}4.10-7.00 \\
6.49 \\
0.91\end{array}$ & $\begin{array}{c}4.10-7.00 \\
6.10 \\
0.76\end{array}$ & $\begin{array}{c}2.00-6.70 \\
4.53 \\
1.23\end{array}$ & $\begin{array}{c}2.00-5.60 \\
3.53 \\
1.00\end{array}$ & $\begin{array}{l}52.134 \\
.0001\end{array}$ \\
\hline
\end{tabular}

There is a significant effect for residence on the QoL. Asthmatic children living in urban areas had higher QoL score than those living in rural areas as illustrated in table (5).

Table (5): Relation between residence and different QoL scores.

\begin{tabular}{|l|c|c|c|}
\hline \multirow{2}{*}{} & \multicolumn{2}{|c|}{ Residence } & \multirow{2}{*}{$\mathrm{T}$} \\
\cline { 2 - 3 } & Urban & Rural & $\mathrm{p}$ \\
\hline OVERALL PAQLQ score & & & \\
Range & $3.0-7.0$ & $1.9-7.0$ & 5.65 \\
Mean & 5.80 & 4.33 & $0.001^{*}$ \\
S.D. & 1.05 & 1.81 & \\
\hline Score of symptoms & & & \\
Range & $2.80-7.00$ & $1.60-7.00$ & \\
Mean & 5.69 & 4.16 & 13.5 \\
S.D. & 1.09 & 1.88 & $0.001^{*}$ \\
\hline Score of activity limitation & & & \\
Range & $2.90-7.10$ & $1.90-7.00$ & \\
Mean & 5.85 & 4.42 & 8.2 \\
S.D. & 1.10 & 1.81 & $0.001^{*}$ \\
\hline Score of emotional function & & & \\
Range & $3.0-7.00$ & $2.00-7.00$ & \\
Mean & 5.92 & 4.55 & 6.02 \\
S.D. & 1.01 & 1.74 & $0.005^{*}$ \\
\hline
\end{tabular}

Table (6) and figure (2) show that there was a obese patients than the normal weight children ( $\mathrm{p}$ significant decrease in overall PAQLQ score in $<0.001)$.

Table (6): Relation between BMI and different QoL scores.

\begin{tabular}{|c|c|c|c|c|c|}
\hline & Under weight & Normal weight & Over weight & Obese & $\begin{array}{l}\mathrm{F} \\
\mathrm{P}\end{array}$ \\
\hline $\begin{array}{l}\text { Overall PAQLQ score. } \\
\text { Range } \\
\text { Mean } \\
\text { S.D. }\end{array}$ & $\begin{array}{c}4.30-6.70 \\
5.87 \\
0.83\end{array}$ & $\begin{array}{c}1.90-7.00 \\
5.82 \\
1.18\end{array}$ & $\begin{array}{c}2.30-6.80 \\
5.01 \\
1.87\end{array}$ & $\begin{array}{c}1.90-7.00 \\
4.31 \\
1.57 \\
\end{array}$ & $\begin{array}{c}9.369 \\
0.0001^{*}\end{array}$ \\
\hline $\begin{array}{l}\text { Score of symptoms } \\
\text { Range } \\
\text { Mean } \\
\text { S.D. }\end{array}$ & $\begin{array}{c}4.20-6.80 \\
5.83 \\
0.79 \\
\end{array}$ & $\begin{array}{c}1.60-7.00 \\
5.71 \\
1.25 \\
\end{array}$ & $\begin{array}{c}2.00-6.70 \\
4.81 \\
1.93 \\
\end{array}$ & $\begin{array}{c}1.60-7.00 \\
4.14 \\
1.61 \\
\end{array}$ & $\begin{array}{c}9.7 \\
0.001 *\end{array}$ \\
\hline $\begin{array}{l}\text { Score of activity limitation } \\
\text { Range } \\
\text { Mean } \\
\text { S.D. } \\
\end{array}$ & $\begin{array}{c}4.40-7.00 \\
5.91 \\
0.88\end{array}$ & $\begin{array}{c}2.30-7.10 \\
5.88 \\
1.20\end{array}$ & $\begin{array}{c}2.10-7.10 \\
5.05 \\
1.98\end{array}$ & $\begin{array}{c}1.90-7.00 \\
4.40 \\
1.55\end{array}$ & $\begin{array}{c}8.75 \\
0.001^{*}\end{array}$ \\
\hline $\begin{array}{l}\text { Score of emotional function } \\
\text { Range } \\
\text { Mean } \\
\text { S.D. }\end{array}$ & $\begin{array}{c}4.40-7.00 \\
5.93 \\
0.88\end{array}$ & $\begin{array}{c}2.00-7.00 \\
5.94 \\
1.13\end{array}$ & $\begin{array}{l}2.80-6.90 \\
5.27 \\
1.72\end{array}$ & $\begin{array}{c}2.00-7.00 \\
4.50 \\
1.54\end{array}$ & $\begin{array}{c}8.91 \\
0.001 *\end{array}$ \\
\hline
\end{tabular}

$F=$ ANOVA test $\quad P$ is significant if $\leq 0.05$ 


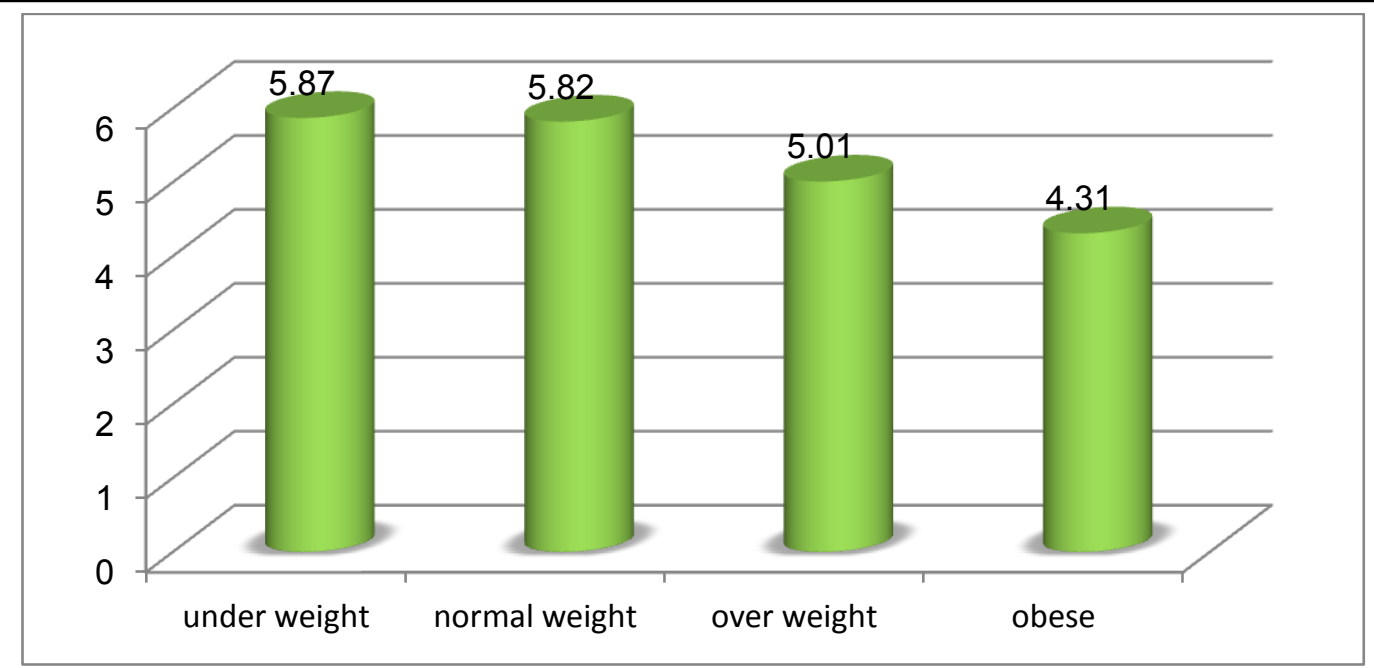

Fig.(2): Relation between BMI and overall PAQLQ score

\section{DISCUSSION}

Asthma is the most frequent chronic disorder in childhood that puts a serious burden on children's HRQL. It accounts for a large proportion of childhood hospitalizations, healthcare visits, absenteeism from school and missed work days by parents. The overall goal of asthma management is to achieve optimal disease control and HRQL improvements. PAQLQ measures the functional (physical, emotional, occupational and social) problems that are most troublesome to children with asthma. The Arabic version of PAQLQ has strong measurement and discriminative properties and has been fully validated for use in both clinical practice and clinical trials. ${ }^{(20)}$

Our study demonstrated that overall PAQLQ score and different scores of the three domains were significantly lower in males than females. This may be attributed to the more severe asthma in males, bad compliance and the more physical activity they practice. This was in conform with the results of previous studies measuring QoL in asthmatic adolescents using PAQLQ in Iran, ${ }^{(21)}$ Brazil $^{(22)}$ and a study conducted at Egypt at Ain Shams University. ${ }^{(23)}$ This was in contrary to the results found in other studies in Canada, ${ }^{(24)}$ Sweden, ${ }^{(25)}$ Jordon, ${ }^{(26)}$ United States ${ }^{(27)}$ and Germany, ${ }^{(28)}$ where the females had lower scores than males.

The study demonstrated that there was insignificant difference in QoL scores among those below 10 years old and those above 10 years old. This may be attributed to poor health services provided to both age groups so different QoL scores are affected similarly in both of them. A study conducted at Israel showed that age has no significant effect on overall QoL score and its subscores and this was attributed there to the close follow up of all age groups. ${ }^{(29)}$ The study of Ain Shams ${ }^{(23)}$ and another one in Serbia ${ }^{(30)}$ demonstrated lower QoL scores among older patients. On the other hand, younger asthmatic children were found to have lower QoL scores than older ones in previous studies from Jordan, ${ }^{(26)}$ United States, ${ }^{(27)}$ Germany $^{(28)}$ and Sweden. ${ }^{(25)}$

The study showed that the overall and different QoL scores are highest among controlled asthmatic children and lowest among uncontrolled asthmatic children.

The score of symptoms was the most affected score among children with different levels of asthma control. This may be related to poor compliance on the controller medications or shortage in the medical services supplied leading to poorer control of asthma and more suffering by the children. The same result was found on two studies, one done to validate the Arabic version of the PAQLQ ${ }^{(20)}$ and another at Ain Shams University. ${ }^{(23)}$ On the other hand, another studies carried on asthmatic children at Sweden, ${ }^{(25)}$ Poland, ${ }^{(31)}$ Brazil $^{(22)}$ and Jordon ${ }^{(26)}$ demonstrated 
that the score of activity limitation was the most affected one.

Our study showed that there was a significant positive correlation between FEV1 and overall PAQLQ score. This is contrary to what was found in a study at Israel where no significant correlation was present between FEV1 and QoL scores. ${ }^{(29)}$

The level of socioeconomic status greatly affected all scores of QoL. Highest scores were reported among high socioeconomic status and lowest scores were present among low socioeconomic status. This is attributed to the higher family income in the high socioeconomic classes that allowed ease of obtaining and consuming the controller medications of asthma.

Residence in urban areas was a main contributing factor for better QoL score. This may be attributed to the ability of children in urban areas to attend regularly to health care services and to obtain their controller medications easily; While in rural areas, there is difficulty to reach these health care services and to obtain controller asthma medications. This was demonstrated in previous studies in Jordon, ${ }^{(26)}$ Serbia $^{(30)}$ and Spain. ${ }^{(32)}$

Our study showed that BMI had a significant effect on QoL of asthmatic children. This was in conform with results of the studies conducted in Canada $^{(33,34)}$ and the United States ${ }^{(35)}$. The study conducted at Ain Shams university did not show a significant effect for BMI on QoL. ${ }^{(23)}$

\section{CONCLUSION AND RECOMMENDATIONS}

Asthma greatly affected the QoL of asthmatic children. Knowing the main determinants of the QoL in affected children helps to improve their QoL. Degree of asthma control, socioeconomic status, residence and $\mathrm{BMI}$ are the main determinants of overall QoL score among the studied children. Improving these QoL determinants might help to improve QoL of these children.

Implementation of PAQLQ as part of routine care with asthmatic children is highly recommended as it will improve not only the quality of care but also the QoL of the asthmatic children which is the real goal of management.

\section{REFERENCES}

1. Global Initiative for Asthma (GINA) Executive Committee. Global strategy for asthma management and prevention. 2017. Available at: http://ginasthma.org/download/317/.

2. Dalheim-Englund AC, Rydstrom I, Rasmussen BH, Moller C, Sandman PO. Having a child with asthma-quality of life for Swedish parents. J Clin Nurs 2004; 13: 386-95.

3. Masoli M, Fabian D, Holt S, Beasley R. Global Initiative for Asthma (GINA) Program. The global burden of asthma: executive summary of the GINA Dissemination Committee report. Allergy 2004; 59: 469-78.

4. Zedan M, Settin A, Farag M, Ezz-Elregal M, Osman E, Fouda A. Prevalence of bronchial asthma among Egyptian school children. Egypt J Bronchol 2009; 3: 12430.

5. Georgy V, Fahim HI, El Gaafary M, Walters S. Prevalence and socioeconomic associations of asthma and allergic rhinitis in northern Africa. Eur Respir J 2006; 28: 756-62.

6. World Health Organization. Asthma fact sheet. 2011. Available at: http://www.who.org (last access at 7 April 2017).

7. Bassili A, Zaki A, Zaher SR, El-Sawy IH, Ahmed MH, Omar M, et al. Quality of care of children with chronic disease in Alexandria, Egypt: the models of asthma, type 1 diabetes, epilepsy, and rheumatic heart disease. Egyptian- Italian Collaborative Group on Pediatric Chronic Diseases. Pediatrics 2000; 106: E12.

8. Bateman ED, Bousquet J, Keech ML, Busse WW, Clark TJ, Pedersen SE. The correlation between asthma control and health status: the GOAL study. Eur Respir J 2007; 29: 56-63. 
9. Guyatt GH, Juniper EF, Feeny DH, Griffith LE. Minimum skills required by children to complete health related quality of life instruments for asthma: comparison of measurement properties. Eur Respir J 1997; 10: 2285-94.

10. Juniper EF, Guyatt GH, Feeny DH, Ferrie PJ, Griffith LE, Townsend M. Measuring quality of life in children with asthma. Qual Life Res 1996; 5:35-46.

11. Donner C, Carone M, Bertolotti G, Zotti A. Methods of assessment of quality of life. Eur Respir Rev 1997; 7: 43-5.

12. Varni JW, Burwinkle TM, Lane MM. Health-related quality of life measurement in pediatric clinical practice: an appraisal and precept for future research and application. Health Qual Life Outcomes 2005; 3: 34.

13. Hahn EA, Cella D, Chassany O, Fairclough DL, Wong GY, Hays RD, et al. Precision of health-related quality-of-life data compared with other clinical measures. Mayo Clin Proc 2007; 82: 124454.

14. Herdman M, Fox-Rushby J, Badia X. Equivalence' and the translation and adaptation of health-related quality of life questionnaires. Qual Life Res 1997; 6: 237-47.

15. Christie MJ, French D, Sowden A, West A. Development of child-centered disease specific questionnaires for living with asthma. Psychosom Med 1993; 55: 541-8.

16. Juniper E. Pediatric Asthma Quality of Life Questionnaire - Arabic version for the United Arab Emirates. 2009. Available at: www. Qoltech.co.uk.

17. Juniper EF, Guyatt GH, Ferrie PJ, Griffith LE. Measuring quality of life in asthma. Am Rev Respir Dis 1993; 147: 832-8.

18. Rowe BH, Oxman AD. Performance of an asthma quality of life questionnaire in an outpatient setting. Am Rev Respir Dis 1993; 148: 675-81.
19. Fahmy SI, El Sherbini AF. Determining simple parameters for social classification for health research. Bull High Inst Public Health 2002; 8: 95-107.

20. Abdel Hai R, Taher E, Abdel Fattah M. Assessing validity of the adapted Arabic pediatric asthma quality of life questionnaire among Egyptian children with asthma. EMHJ 2010; 16: 274-80.

21. Zandieh F, Moin M, Movahedi M. Assessment of quality of life in Iranian asthmatic children, young Adults and their caregivers. Iran J Allergy Asthma Immunol 2006; 5: 79-83.

22. Nogeira KT, Silva JL, Lopes CS. Quality of life in asthmatic adolesects: assessment of asthma severity, comorbidity, and life style. J Pediatr 2009; 85: 523-30.

23. Al-Gewely M, El-Hossainy M, Abou Elezz N, El-Ghoneimy D, Hassan A. Health related quality of life in childhood bronchial asthma. Egypt J Pediatr Allergy Immunol 2013; 11: 83-93.

24. Juniper EF. Effect of asthma on quality of life. Can Respir J 1998; 5: 77A-84A.

25. Rydstorm I, Dalheim-Englund AC, Holritz-Rasmussen B, Moller C, Sandman PO. Asthma quality of life for Swedish children. J Clin Nurs 2005; 14: 739-49.

26. Al-Akour N, Khader YS. Quality of life in Jordanian children with asthma. Int J Nurs Pract 2008; 14: 418-26.

27. Schmier JK, Chan KS, Leidy NK. The impact of asthma on health-related quality of life. J Asthma 1998; 35: 585-97.

28. Warscburger P, Busch S, Bauer CP, Kiosz D, Stachow R, Petermann F. Healthrelated quality of life in children and adolescents with asthma: results from ESTAR study. J Asthma 2004: 41: 463-70.

29. Mussaffi H, Omer R, Prais D, Mei-Zahav $\mathrm{M}$, Weiss-Kasirer $\mathrm{T}$, Botzer $\mathrm{Z}$, et al. Computerized pediatric asthma quality of life questionnaires in routine care. Arch Dis Child 2007; 92: 678-82. 
30. Tomic Spirić V, Bogić M, Janković S, Maksimović N, Matovic Miljanović S, Peric Popadić A, et al. Assessment of the Asthma Quality of Life Questionnaire (AQLQ): Serbian Translation. Croat Med J 2004; 45: 188-94.

31. Farnik M, Pierzchala W, Brożek G, Zejda JE, Skrzypek M. Quality of life protocol in the early asthma diagnosis in children. Pediatr Pulmonol 2010; 45: 1095-102.

32. Garcia ML, Carvajal UI, Escribano MA, Fernandez MB, Garcia RS, Tauler TE, et al. Seasons and other factors affecting the quality of life of asthmatic children. J Investig Allergol Clin Immunol 2007; 17: 249-56.

33. van Gent $R$, van der Ent CK, Rovers MM, Kimpen JL, van Essen Zandvliet LE, Meer G. Excessive body weight is associated with additional loss of quality of life in children with asthma. J Allergy Clin Immunol 2007; 119: 591-6.

34. Lavoie KL, Bacon SL, Labrecque M, Cartier A, Ditto B. Higher BMI is associated with worse asthma control and quality of life but not asthma severity. Respir Med 2006; 100: 648-57.

35. Ford ES, Mannino DM, Redd SC, Moriarty DG, Mokdad AH. Determinants of quality of life among people with asthma: findings from the Behavioral Risk Factor Surveillance System. J Asthma 2004; 41: 